\title{
Household Saving Behaviour in Kenya: A Discrete Choice Approach
}

\author{
Isaac Wachira Mwangi \\ Research Department, Central Bank of Kenya, \\ Box: 60000-00200 Nairobi, Kenya
}

\begin{abstract}
Domestic saving in developing countries remains relatively low compared to the developed World despite its huge significance as a growth and investment stimulant. Recent evidence from Word Bank Development Indicators reveal a decline in the Gross Domestic Savings as a percentage of GDP from 9 percent in 2008 to 5.32 percent in 2018. Kenya's 2019 FinAccess household survey affirms that households account for a sizeable share of the gross national savings. Although 55 percent of the total adult population hold atleast one formal saving account, gender and geographical disparities in formal saving persist averaging 10 percent and 23 percent, respectively. Viewed against the backdrop of low saving rates and the growing need to enhance saving mobilization to finance Kenya's overall investment needs, this study utilized binary logit and multinomial probit to model household saving behaviour. The study established that both socioeconomic and household demographic characteristics shape household saving behaviour in Kenya. In particular, uptake of formal saving rises with the level of urbanization and formality of employment but decline with family size. The study recommends investment in financial education and financial literacy programs and promotion of economic activities to boost savings.
\end{abstract}

Keywords: Discrete choice; Saving; Household

JEL Codes: G21, C35, D11

DOI: $10.7176 / \mathrm{JESD} / 11-4-10$

Publication date: February $29^{\text {th }} 2020$

\subsection{Introduction}

The role played by savings in propelling growth and investments cannot be over emphasized. At the national level, domestic savings provide the means for capital formation, which acts as a central pillar for economic development. Adewuyi, Bankole, \& Arawomo (2010) associated savings with financial stability, economic growth, poverty reduction, sustained development and macroeconomic balance. Harrod and Domar model link variations in countries growth paths to differences in saving and investment rates. For countries that consistently achieve a top growth rate, most of them, also record highest rates of investment. Elbadawi \& Mwega (2000) demonstrated that high national saving is a prerequisite for avoiding financial pitfalls and the subsequent collapse of growth. Unfortunately, saving in Sub-Saharan Africa and Kenya in particular trails other regions besides being considerably unstable. Figure 1 presents the gross national saving as a percentage of GDP in select countries.

Figure 1: Gross saving (\% of GDP) in Select Countries

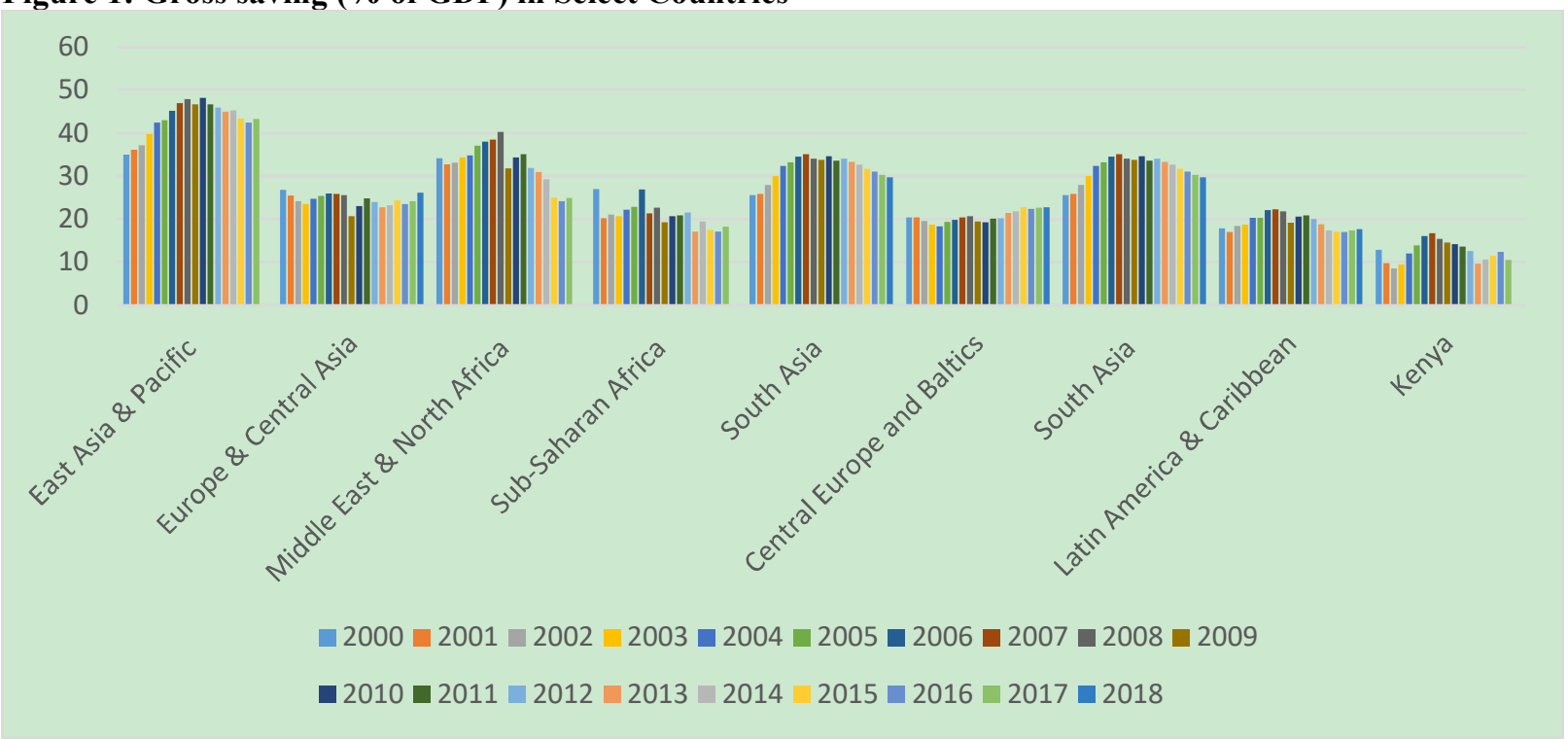

Source: World Bank Development Indicators, 2019

Despite the growing interest in saving studies, a majority are unequivocally biased towards macroeconomic aggregates. Specific literature on household saving behaviour in Kenya remains relatively scarce with only handful 
studies showing interest despite the growing significance. Consumption and saving theories and particularly the Life Cycle Hypothesis ( $\mathrm{LCH}$ ) have established a strong link between saving mobilization and income. The theory suggests that the present value of lifetime utility is maximized subject to the budget constraint, often derived from the sum of current net worth and the present value of expected income over their lifetime.

Each stage in one's life cycle undoubtedly shapes saving decisions owing to the obvious fluctuations in income with savings peaking during productive years before assuming a sharp descent upon retirement. Saving even in the productive years could be hampered by the uncertainty witnessed among households with respect to income generation and subsistence consumption. Ersado et al. (2000) attributes this to natural, market and institutional risks faced by households in generating means of survival. A recent study by Njenga, Onuonga and Sichei (2018) has underscored the role of income in driving savings.

Kenya's savings as a share of GDP have remained relatively low in the last decade at times fluctuating widely from year to year. Data estimates from World Bank for the years 2000-2018, indicate that gross domestic savings as a share of GDP averaged 5.3 percent in 2018 down from 6.7 percent in $2000^{1}$. This could partly be explained by the ease of accessing cash using mobile phones, high cost of living and rising consumption. This period also witnessed a decline in investment as a percent of GDP to 8.43 percent in 2018 down from 11.11 percent in 2000 leaving a 3.13 percent resource gap to be financed from other sources mainly external. This resource gap paints a gloomy picture of the country's future investment trajectory having grown from negative 3.45 percent in 19901999.

World Bank (1993) expressed the view that East Asia countries that reported high investment and growth from 1960 to date are characterized by over 30 percent gross national saving rate to GDP ratio. In addition, this stunted growth in savings could hamper the attainment of the Vision 2030 goal of double-digit economic growth. Seminar Paper No. 10 posit that self-sustaining growth requires domestically generated savings (Republic of Kenya, 1965).

Although international capital flows can supplement domestic savings, concerns over external indebtedness and dependence not to mention the volatile character of the global capital market curtails the reliance on capital flows in the long-run. The ratio of Government debt to GDP in 2018 averaged 57 percent $^{2}$ limiting the reliance on debt to finance investment projects. This is especially so at a time where development of the financial system, in Kenya, is becoming of crucial importance. Savings rate remains relatively low despite the country undertaking a series of financial reforms to improve economic performance.

Most studies ignore household savings instead choosing to focus on aggregate savings position despite household savings taking the lions share (United Nations, 1962). Using discrete choice models, this study seeks to fill this gap by examining household saving behaviour and the factors that inform their choices. Modeling of the formal and informal saving models is motivated by the life cycle hypothesis. In addition, the study provides a sub region ranking of saving options in Kenya.

\subsection{Household Saving Mode in Kenya}

Table 1: Household Saving Options in Kenya (\%)

\begin{tabular}{|l|r|r|l|r|r|r|r|r|r|r|r|}
\hline $\begin{array}{l}\text { Saving } \\
\text { Mode }\end{array}$ & MFI & $\begin{array}{l}\text { Mobil } \\
\text { e Bank }\end{array}$ & $\begin{array}{l}\text { Mobil } \\
\text { Mone }\end{array}$ & $\begin{array}{l}\text { SAC } \\
\text { CO }\end{array}$ & $\begin{array}{l}\text { Cham } \\
\text { a }\end{array}$ & $\begin{array}{l}\text { Group of } \\
\text { Friends }\end{array}$ & $\begin{array}{l}\text { Secret } \\
\text { Hidin } \\
\mathrm{g}\end{array}$ & $\begin{array}{l}\text { Post } \\
\text { ban } \\
\mathrm{k}\end{array}$ & Bank & $\begin{array}{l}\text { Form } \\
\text { al }\end{array}$ & $\begin{array}{l}\text { Infor } \\
\text { mal }\end{array}$ \\
\hline $\begin{array}{l}\text { Current } \\
\text { use }\end{array}$ & 1.5 & 16.8 & 43.6 & 10.9 & 29.2 & 7.7 & 23.6 & 0.7 & 7.7 & 55 & 29 \\
\hline Used to & 1.1 & 5.3 & 4.7 & 2.4 & 5 & 3.4 & 5.7 & 1.5 & 1.4 & 4.1 & 5 \\
\hline Never & 97.4 & 77.9 & 51.6 & 86.7 & 65.8 & 88.9 & 70.7 & 97.9 & 90.9 & 40.9 & 66 \\
\hline
\end{tabular}

Source: FinAccess, 2019

Table 1 shows that current usage of formal and informal saving in 2019 averaged 55 percent and 29 percent respectively locking out a huge proportion of the adult population despite the significant role savings could play in smoothing consumption and investment. Harrod Domar opines that savings can play a critical role in minimizing reliance on external borrowing through rapid capital formation. In terms of choice of saving products, the data shows that a majority prefer to save in mobile wallets (43.6 percent) followed by informal groups (chamas) at 29.2 percent and secret hiding places (23.6 percent) in that order. Figures 2 and 3 provide insights on the drivers and barriers of savings in Kenya respectively.

\footnotetext{
${ }^{1}$ https://data.worldbank.org/indicator/NY.GDS.TOTL.ZS?locations=KE

2 https://tradingeconomics.com/kenya/government-debt-to-gdp
} 
Figure 2: Drivers of Saving in Kenya

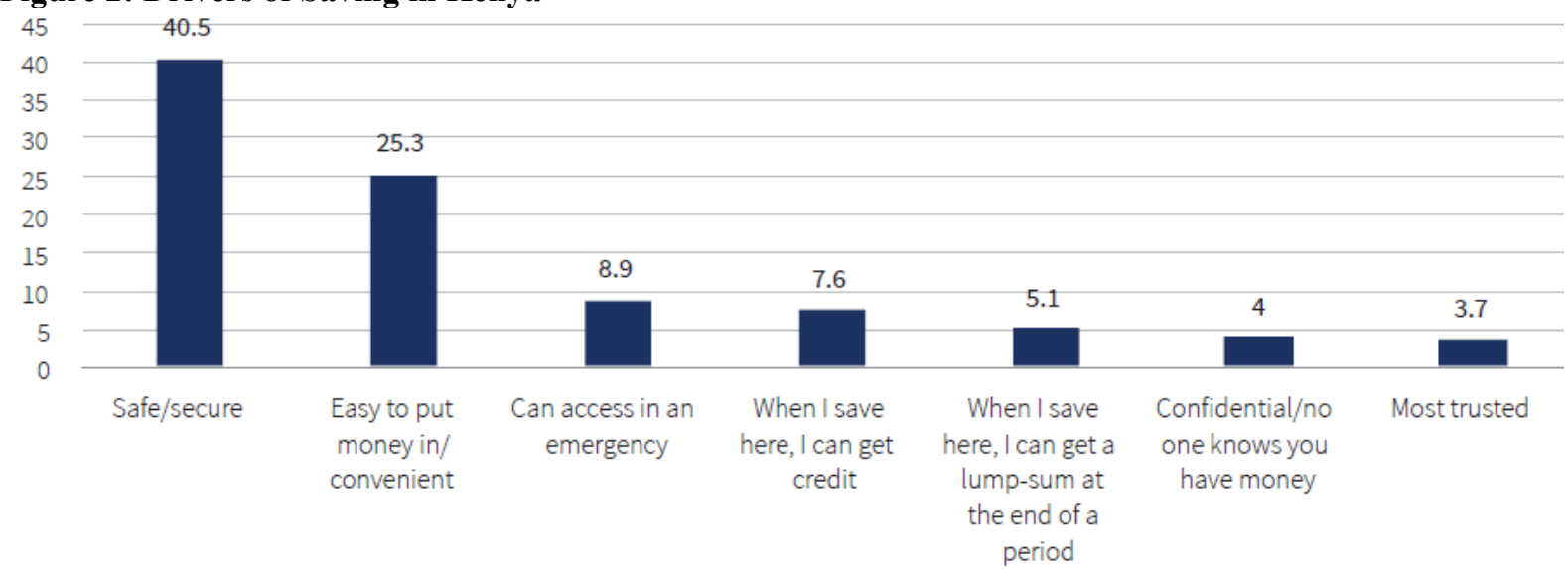

Source: FinAccess, 2019

The 2019 FinAccess Household Survey Report cites safety/security concerns (40.5 percent) and the ease of saving money/convenience ( 25.3 percent) as the main drivers of savings in Kenya. Other factors driving the usage of savings account for 35.2 percent.

Figure 3: Barriers of Saving in Kenya

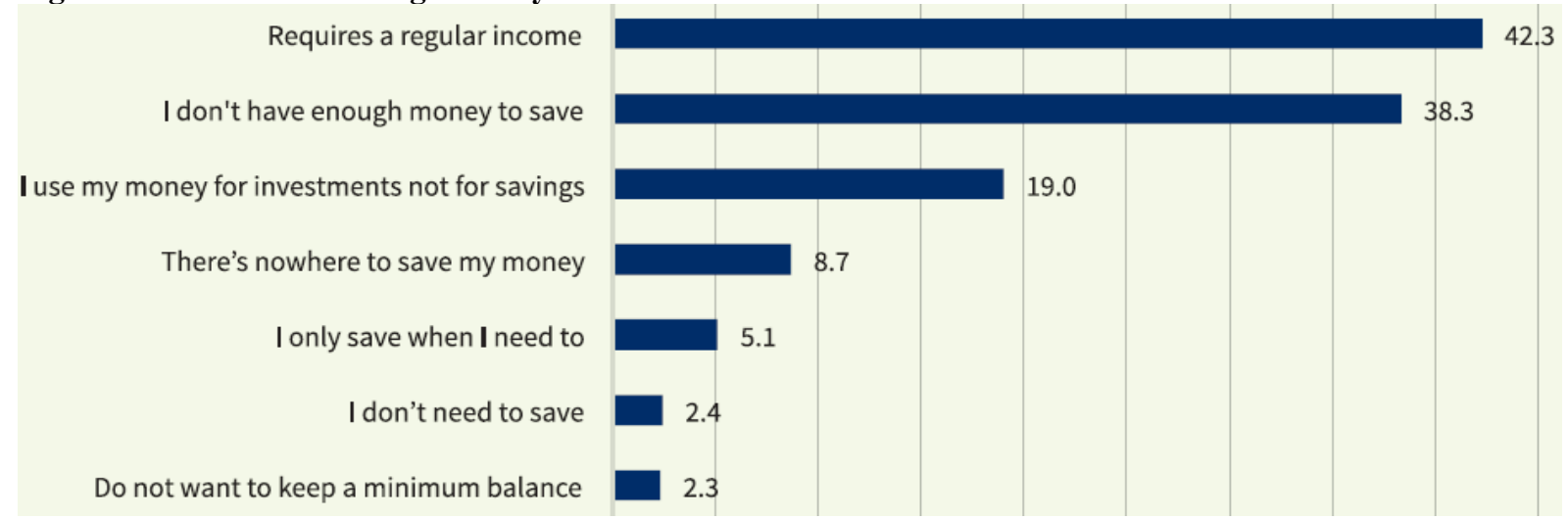

Source: FinAccess, 2019

Barriers to saving in Kenya for a vast majority ( 80.6 percent) were found to be income related with need for regular income and lack of money to save accounting for 42.3 percent 38.3 percent respectively.

A study by Elbadawi \& Mwega (2000) found Kenya's domestic savings to be dominated by private saving, earning the issue fresh impetus to investigate it. Unmasking household saving behavior is of great import to policy makers, management of financial institutions and future researchers given the limited attention it has received.

The remainder of the paper is organized as follows. Section 2 discusses the overview of literature. Section 3 presents the theoretical framework, methods and data. Section 4 discusses findings while Section 5 gives conclusions and recommendations for policy.

\subsection{Literature Review}

Whereas Solow's Neoclassical growth model predicts convergence to a steady state and a balanced growth path in the long run when the output, capital and labour inputs grow at the same rate, Harrod Domar model amplified the critical role played by savings and capital accumulation in predicting the long run growth path. Saving studies are motivated by microeconomic theory of consumer choice which gives a mirror image. These consumption theories include; Keynes(1936) absolute income hypothesis, life cycle hypothesis by Modigliani and Brumberg (1954), Modigliani and Ando, (1957; 1963); Friedman (1957) permanent income hypothesis, Dusenberry (1949) relative income hypothesis, Diamond (1965) Overlapping Generation Model and Hall (1978) Random Walk Hypothesis, psychological, behavioral and sociological theories. Factors likely to "psychologically" induce savers to increase consumption hence decreasing saving and relax income generation efforts include domestic credit, government policies with regard to wealth distribution and welfare payments, contribution to public saving and degree of dependence on foreign aid.

Both life cycle hypothesis and permanent income hypothesis argue that households maximize utility by maintaining a balance between future income streams and consumption hence often treated as identical. During early years, consumption needs are more than income even though the income earned rise at the middle age, which 
helps in paying off the accumulated debt, and leave some surplus. After retirement, the accumulated savings compensate the decline in income. This is because consumption needs and income earned vary throughout the life cycle. This theory differs slightly from the relative income hypothesis, which posits that households look at consumption in relative terms as opposed to absolute consumption.

Modigliani and Brumberg (1954) seminal paper on the life cycle model demonstrates the saving potential to transfer an economic agent's purchasing power from one phase of life to another. This is echoed by Diamond (1965) who argues that household's consumption in the second period is drawn from savings in the first period. Since economic agents want to smooth consumption throughout their life, during their early lives, they will borrow and build up their wealth during high-income years and spend off the accrued savings upon retirement. Hall (1978) posits that consumption changes are independent of the changes in income. As such, consumption only depends on the present value of the lifetime income. The savings grow gradually during the early working years, peaks later in life before falling to negative levels after retirement. The negativity of the saving rate is however, not guaranteed since the time of death is uncertain. Utility maximization in the life cycle hypothesis is often limited by the lifetime budget constraint that links consumption at various periods in their lifetime. The life cycle model of saving is considered robust in explaining the effect of demographic factors on household saving rate (Kauffmann, 1991).

Consistent with theory, an examination of empirical literature on demand for household savings produces interesting findings. A consistent finding by numerous authors is that there is more than one factor influencing household saving behavior. A number of recent empirical studies have estimated the effect of various economic and demographic variables on private saving rates at both micro and macro levels. Despite the studies having different dimensions given that they are based on different sample periods, countries, model specifications and estimation techniques, the studies seem to be consistent in terms of the expected signs of the estimable parameters. The only point of departure for most studies is the coefficient of saving at old age, which is not necessarily negative (King, 1985). This is however, accounted for by controlling for aversion of individuals to uncertainty about the future, the presence of pension schemes and reduced consumption due to health complications.

As stipulated in Keynes(1936) absolute income hypothesis, empirical studies on household demand for savings found that savings rates were significantly positively determined by the level of private disposable income (Kibet et al. (2009) ; Elbadawi I. A. \& Mwega, F. M. (2000); Nga M.T. ( 2007); Loayza, et al (2000) ). At the same time studies by Loayza, et al (2000), and Mwega, et al (1990) show that there are adjustment lags in saving behaviour as the full reaction of savers to changes is not instantaneous but occurs over time.

According to McKinnon and Shaw doctrine, the law of negative real interest rates discourage savings mobilization and the channeling of the savings through the financial system. The doctrine has been supported by some empirical studies such as Elbadawi I. A. \& Mwega (, F. M. (2000) who from their studies show that real rate of interest had a positive and significant coefficient on private savings. However, results from an earlier study by Mwega, et al (1990), the data running from 1965-1985 revealed that the real deposit rate had an insignificant impact on the real saving rate in Kenya.

Standard models of savings depict an inverse relationship between savings and credit. The reasoning behind this is that the urge to hold precautionary savings for use during emergencies is secondary where there is ease of access to credit services. Rogg (2000) however disputes this in a study tagetting micro-entrepreneurs in Ecuador, Salvador and Paraguay where savings increased with increase in credit. Kiiza and Pederson (2002) study on determinants of household savings in Uganda using logistic model singled out education, urbanization and income as drivers of savings.

Artyeetey (2004) introduced the use of assets as a saving tool. In a study on Ghana, on asset holding and households characteristics, the author argued that faced with income shocks, households opt to smooth their consumption through crop diversification. The low income earners were found to hold their welath in form of livestock and farms, middle income earners land and non farm enterprises while even as high income earners opted for bank savings. This literature stream however introduces difficulties in the measurement of savings due to socieoeconomic and cultural differences among households. In Kenya for eample, communities living in Northern parts are likely to hold their savings in form os livestock. The same applies to Central region which has a higher attachment to land. To control for these, the current study limits itself to the savings captured in financial form.

Recent literature also associates both household characteristics and institutional factors with household savings. Njenga, Onuonga and Sichei (2018) for example established a strong correlation between formal education and saving probability. Using multinomial probit, the study modelled savings in levels, categorizing it into; low savings (less than half of monthly income), moderate savings (half monthly income) and high savings (greater than half monthly savings) using the 2006, 2009 and 2013 FinAccess household survey data. Other independent variables found to significantly influence the observed savings behavior include; dependency ratio, age, income, household size, urbanization, gender, marital status and institutional factors.

Schunk (2007) in a study on the saving behavior of German households' found consumption needs after retirement; need to insure against various economic, biometric, and political risks that an individual is exposed to 
over the life cycle; need to support children or grandchildren; need to acquire real estates at some point in their lives as some of the factors. Others studies including William et al., 2012; Atieno, 2001; Chowa et al., 2012; Boring, 2010; Newman et al., 2007; Carpenter and Jensen, 2002; Mwega, et al., 1990; Kibet et al., 2009; Elbadawi I. A. \& Mwega, F. M., 2000; Loayza, et al., 2000; Amimo et al., 2003; Hilgert, Hogarth and Beverly, 2003 identified household head characteristics and institutional factors such as income, education, gender, age, marital status, trust in the financial institution, service charge, transport costs, household size, years of schooling, dependency ratio, locality, physical and financial wealth as regressors. A recent study on household savings in Kenya by Kibet et al., (2009) included interest rate earned by holding savings in a financial institution for atleast two months and transport cost to the financial institution as independent variables.

A general observation from the reviewed literature is that a number of studies including Amimo et al., (2003) relied on a relatively small sample limiting aggregaration at the national level. Other studies like Newman et al., 2007 relied only on descriptive statistics to explain savings in formal and informal institutions. This narrow focus could limit a thorough examination of household savings. The current study overcomes sampling bias by using nationally representative household survey data. In addition the study employs discrete choice models i.e. binary logit and multinomial probit to model differences in the choice of formal and informal saving options among Kenyan households across the sub regions, income groups, education, agegroups, gender, livelihoods, financial health, trust levels, pricing and financial literacy. The study also disaggregates formal savings to accomodate both digital and non digital saving options from formal institutions.

\subsection{Methods and Data}

\subsection{Theoretical Framework}

As mentioned earlier, the theory of saving is the mirror image of the theory of consumption. In this regard, any theory used to explain how households allocate income to consumption can also be used to explain the saving since income is distributed between the two components. The study particularly borrows from both the life cycle hypothesis $(\mathrm{LCH})$ and permanent income hypothesis $(\mathrm{PIH})$ which attribute changes in current consumption as being dependent on expected long term income even though households in the LCH differ slightly from the infinitely lived households in the PIH for featuring a finite lifetime with a distinct period of retirement at the end. The main features of the LCH are employed with slight modification to include specific characteristics of Kenyan households.

Romer (2005) uses the theory of consumption under the permanent income theory to define savings. Under this theory, an individual who lives for a life period $(\mathrm{T})$ is assumed to have a utility function of the following form;

$U=\sum_{t=1}^{T} u\left(C_{t}\right)$

$$
u^{\prime}(\bullet)>0, \quad u^{\prime \prime}(\bullet)<0
$$

Where $C_{t}$ is consumption in period t and $u(\bullet)$ represents the instantaneous utility function. The individual has an initial endowment of wealth $\left(A_{o}\right)$ and labour incomes over his or her life time-period T $\left(Y_{1}, Y_{2}, \ldots, Y_{T}\right)$, which are taken as given. It is assumed that the individual can save or borrow at an exogenous rate of interest, and any outstanding debt has to be repaid at the end of his or her life time. The budget constraint of the individual is of the following form;

$$
\sum_{t=1}^{T} C_{t} \leq A_{0}+\sum_{t=1}^{T} Y_{t}
$$

Given that $\left(u^{\prime}(\bullet)>0,\right)_{3}$ an individual's consumption expenditure corresponds to their budget constraint, and hence, the individual's optimization problem can be written as follows;

$L=\sum_{t=1}^{T} u\left(C_{t}\right)+\lambda\left(A_{0}+\sum_{t=1}^{T} Y_{t}-\sum_{t=1}^{T} C_{t}\right)$

From the first-order condition for utility maximization, the marginal utility of consumption is constant over time. Since the level of consumption determines its marginal utility, consumption is also assumed to be constant over time. Factoring this notion into the budget constraint leads to the following equation.

$C_{t}=\frac{1}{T}\left(A_{0}+\sum_{t=1}^{T} Y_{\tau}\right)_{\text {for all } \mathrm{t}}$

The items captured in parenthesis in equation 4 represent an individual's total lifetime resource (initial wealth and

\footnotetext{
${ }^{3}$ Marginal utility of consumption is always positive
} 
lifetime labour income). The equation further shows that an individual consumes an equal amount of resources in each period of their lifetime. From the consumption saving relation;

$$
S_{t}=\left(Y_{t}-\frac{1}{T} \sum_{t=1}^{T} Y_{\tau}\right)-\frac{1}{T} A_{0}
$$

Equation 5 shows that saving becomes negative when permanent income exceeds current income, which acts as the foundation of permanent-income hypothesis (Romer, 2005). With the PIH, savings is regarded as future consumption and as such, the opportunity cost of postponing current consumption for a high level of future consumption is the interest rates. Equation 2 is expressed as follows:

$$
\sum_{t=1}^{T} \frac{1}{(1+r)^{t}} C_{t} \leq A_{0}+\sum_{t=1}^{T} \frac{1}{(1+r)^{t}} Y_{t}
$$

From equation 6 , equation 5 can be expressed as;

$$
S=\left\{\left(Y_{t} / 1+r\right)-\frac{1}{T} \sum_{\tau=1}^{T}\left(Y_{\tau} / 1+r\right)\right\}-\frac{1}{T} A_{0}
$$

From equation 7, it is seen that there is a possibility that savings would increase when the present value of current income is high relative to its average. However, given that interest rate constitute both substitution and income effects, an increase in the present value of income will not necessarily lead to increase in savings. The change would depend on which factor overrides the other.

The absence of a link between current saving and current income in the $\mathrm{LCH}$ is an implication that individuals are forward-looking, and therefore, base their saving decisions on lifetime income rather than current income (Ando \& Modigliani, 1963). This approach is applied in the current study with modifications to incorporate demographic household characteristics.

\subsection{Empirical Model}

Both a binary and multinomial choice models are employed in the current study. This is motivated by McFadden (1974) Random Utility Hypothesis, which assumes that a household who is confronted with various options opts for that savings option which derives the highest utility.

The utility function is expressed as follows:

$U_{\text {in }}=V_{\text {in }}+\varepsilon_{\text {in }}$

Where; $V_{\text {in }}$ represents the deterministic utility while ${ }^{\varepsilon_{\text {in }}}$ represents the uncertainty in household utility. $i$ is the savings option while $\mathrm{n}$ is the household.

The probability that option $i$ is picked from choice set $C_{n}$ is expressed as follows:

$$
P\left(i \mid C_{n}\right)=P\left[U_{i n} \geq U_{j n} \forall j \in C_{n}\right]=P\left[U_{i n}=\underset{j \in C_{n}}{\max } U_{j n}\right]
$$

For the binary logit, the choice is made from two alternatives defined by $j$ but in the case of multinomial probit, the choice is made from three alternatives defined by the following general specification.

$$
p i j=\operatorname{Pr}\left[s_{i}=j\right]=F_{j}\left(x_{i} \beta\right), j=1,2, \ldots, m, i=1,2, \ldots, N
$$

Where; ${ }^{x_{i}}$ are regressors, $\beta$ the parameter estimates, $j_{\text {the possible alternatives and }} F_{j}$ the functional form with probabilities lying between 0 and 1 .

The multinomial probit in the context of this paper has been used for robustness check with the estimation results appendicized. Multinomial probit model assumes that the error terms are multivariate normally distributed and are correlated across the choices. This corrects for the blue bus red bus paradox in multinomial logit, which implies that introducing a new alternative has the potential to alter household choice (Cameron and Trivedi, 2005). This model is superior to the multinomial logit for allowing correlation of residuals to counter the Independence of Irrelevant Alternatives (IIA) problem. Mwangi \& Sichei (2011) and Njenga, Onuonga \& Sichei (2018) have used multinomial probit to model the full correlation matrix of the residuals.

The saving decision by a household is expressed using the following demand function:

Savings_demand $=S=\beta_{0}+\beta_{z}^{\prime} Z_{i}+\varepsilon_{i}$ 
$(i=, \ldots, N)$

$S$ is the dependent variable and represents the demand for savings products classified as digital formal, formal, non-digital formal and informal. $Z$ is a vector of household characteristics, which are discussed in Table 2.

Table 2: Definition of Variables and Expected Signs

\begin{tabular}{|c|c|c|c|}
\hline Variable & Measurement & $\begin{array}{l}\text { Expected } \\
\text { Sign }\end{array}$ & Description \\
\hline $\begin{array}{l}\text { Household } \\
\text { Size }\end{array}$ & $\begin{array}{l}\text { Total number of people living in } \\
\text { the household. }\end{array}$ & Positive & Amimo et al., 2003 \\
\hline Education & $\begin{array}{l}\text { Based on the highest education } \\
\text { level attained. }\end{array}$ & Positive & $\begin{array}{l}\text { Kiiza and Pederson, 2002; Amimo et al., } \\
\text { 2003; Kibet et al., 2009 }\end{array}$ \\
\hline Residence & $\begin{array}{l}\text { Based on respondent dwelling } \\
\text { place }\end{array}$ & $\begin{array}{l}\text { Positive } \\
\text { (urban) }\end{array}$ & $\begin{array}{l}\text { Kiiza and Pederson, 2002; Loayza, et al., } \\
\text { 2000; Atieno, } 2001\end{array}$ \\
\hline Age & $A$ ge of respondent (in years) & Positive & $\begin{array}{l}\text { Elbadawi \& Mwega, 2000; Amimo et al., } \\
\text { 2003; } \\
\text { Kibet et al., } 2009\end{array}$ \\
\hline $\begin{array}{l}\text { Age } \\
\text { squared }\end{array}$ & $\begin{array}{l}\text { Squared age of respondent (in } \\
\text { years) }\end{array}$ & Negative & $\begin{array}{l}\text { Elbadawi \& Mwega, 2000; Amimo et al., } \\
\text { 2003; } \\
\text { Kibet et al., } 2009\end{array}$ \\
\hline Gender & $\begin{array}{l}1 \text { if respondent is male otherwise } \\
\text { zero. }\end{array}$ & $\begin{array}{l}\text { Negative } \\
\text { (Female) }\end{array}$ & Kibet et al., 2009 \\
\hline $\begin{array}{l}\text { Marital } \\
\text { Status }\end{array}$ & $\begin{array}{l}1 \text { if respondent is married } \\
\text { otherwise zero }\end{array}$ & $\begin{array}{l}\text { Positive } \\
\text { (Married) }\end{array}$ & Njenga, Onuonga \& Sichei (2018) \\
\hline Income & Based on income group. & Positive & $\begin{array}{l}\text { Kiiza and Pederson, 2002; Amimo et al., } \\
2003 \text {; } \\
\text { Kibet et al., 2009; Carpenter and Jensen, } \\
2002\end{array}$ \\
\hline Livelihood & $\begin{array}{l}\text { Based on respondent main } \\
\text { economic activity }\end{array}$ & $\begin{array}{l}\text { Negative } \\
\text { (Dependent) }\end{array}$ & $\begin{array}{l}\text { Amimo et al., 2003; Njenga, Onuonga \& } \\
\text { Sichei, } 2018\end{array}$ \\
\hline $\begin{array}{l}\text { Financial } \\
\text { Literacy }\end{array}$ & $\begin{array}{l}\text { Based on respondent financial } \\
\text { literacy status }\end{array}$ & Positive & $\begin{array}{l}\text { Chowa et al., 2012; William et al., 2012; } \\
\text { Hilgert, Hogarth and Beverly, } 2003\end{array}$ \\
\hline Trust & $\begin{array}{l}\text { Seek financial assistance from } \\
\text { Bank/Sacco when in need }\end{array}$ & Positive & Njenga, Onuonga \& Sichei (2018) \\
\hline Price & $\begin{array}{l}\text { Pays above KSh } 100 \text { to access the } \\
\text { nearest Bank }\end{array}$ & Negative & $\begin{array}{l}\text { Kibet et al., 2009; Njenga, Onuonga \& } \\
\text { Sichei, 2018; Chowa et al., } 2012\end{array}$ \\
\hline $\begin{array}{l}\text { Financial } \\
\text { Health }\end{array}$ & $\begin{array}{l}\text { Based on respondent financial } \\
\text { health status }\end{array}$ & Positive & FinAccess (2019) \\
\hline
\end{tabular}

\subsection{Data and Sources}

The study utilized Kenya's 2019 FinAccess Household Survey data to estimate simple logit and multinomial probit models. The survey data is collected through a public private partnership arrangement that draws its membership from the Central Bank of Kenya (CBK), Kenya National Bureau of Statistics (KNBS) and Financial Sector Deepening (FSD Kenya). The FinAccess surveys are conducted every three years to track developments in the financial sector. Other parties involved in the design of the survey instruments include; Financial Sector Regulators, Commercial Banks and other players in the industry. The data is representative at the national, rural urban and at the sub-regions which are 13 in number (Appendix Table 5). The sub-regions are demarcated based on geographic, economic and demographic indicators.

The simple logit model uses a binary dependent variable (formal saving, digital and non-digital saving) represented using 1 if using and 0 otherwise. The digital saving model combines mobile banking savings account and savings account with mobile money. On the other hand, the dependent variable under the multinomial probit is categorized as; formal saving, informal saving or excluded for those who save with friends and/or family or their saving mode is unknown. Although the survey-interviewed individuals aged 16 years and above, analysis is based on individuals aged 18 years and above (Kenya's definition of an adult) which is approximately 25,104,600 people. The Survey utilized the KNBS NASSEP V sampling framework with a sample size of 11,000 households. A threestage cluster sample design was followed where; stage 1 focused on selection of clusters from the sampling frame, stage 2 entailed selection of households from each cluster while stage 3 helped select one individual to be interviewed from each household. 


\subsection{Findings and Discussions}

The study established that access to savings products varies with the changes in the demographic characteristics of Kenyan households. Discussion of empirical estimation results is preceded by a correlation matrix presented in Table 3.

Table 3: Correlation coefficients

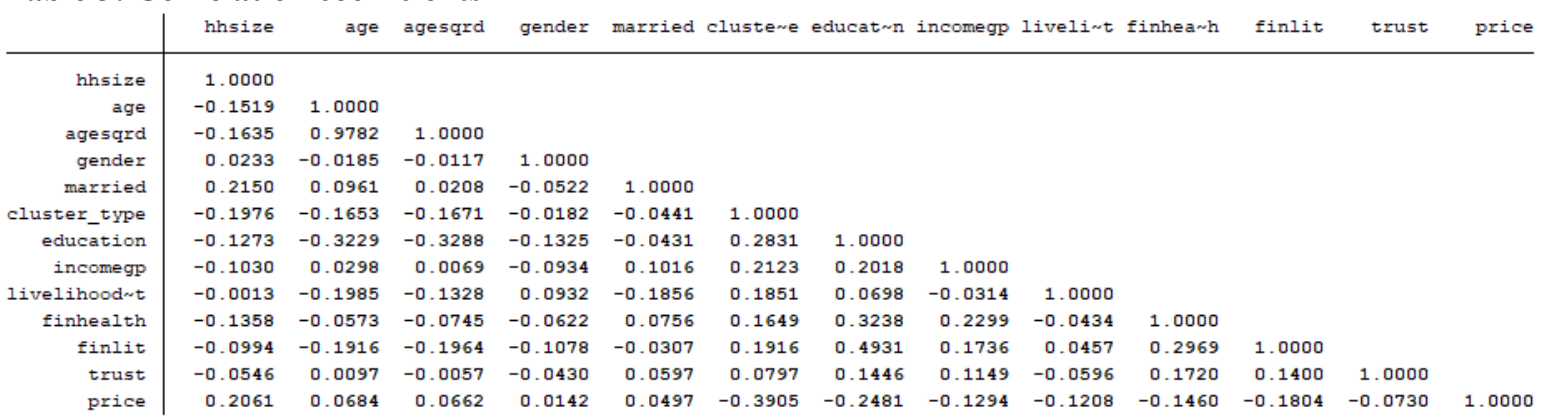

Source: Author, 2020

A strong relationship between the endogenous and exogenous variables was established. Correlation coefficients only raise concern when they exceed 0.8 because in that case they imply there is perfect multicollinearity problem. None of the analysed variables exceeds the 0.8 threshold hence ruling out multicollinearity problems in the model.

\subsection{Econometric Analysis}

Analysis of household saving behaviour in Kenya follows a discrete choice approach given the non-linearity of choices made. Given that the estimated coefficients (odds ratio) in discrete choice models cannot be relied upon in drawing inference except informing the direction of causality from the coefficient sign, changes in household saving probabilities are explained using the marginal effects. To avoid falling into a dummy variable trap, the model includes a reference category, to explain the change. Table 4 discusses the logit estimation results on the choice of formal saving, formal digital saving and formal non-digital saving. The estimation results for the multinomial probit are presented in Appendix Table 6 for robustness checks.

Table 4: Binary Logit Estimation

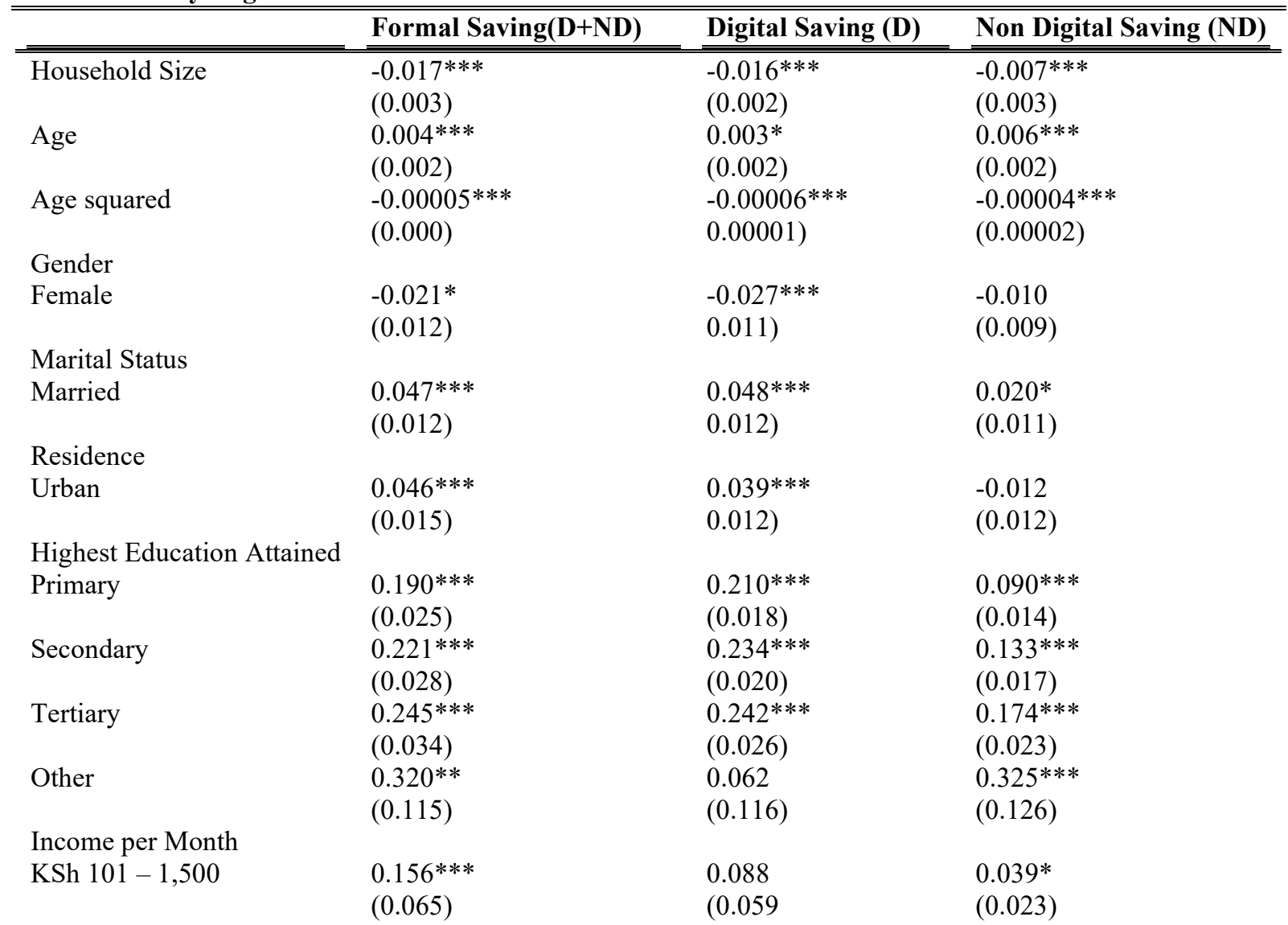




\begin{tabular}{|c|c|c|c|}
\hline KSh $1,501-3,000$ & $\begin{array}{l}0.255 * * * \\
(0.065)\end{array}$ & $\begin{array}{l}0.188 * * * \\
(0.059)\end{array}$ & $\begin{array}{l}0.101 * * * \\
(0.023)\end{array}$ \\
\hline KSh 3,001-7,500 & $\begin{array}{l}0.286 * * * \\
(0.066)\end{array}$ & $\begin{array}{l}0.221 * * * \\
(058)\end{array}$ & $\begin{array}{l}0.114 * * * \\
(0.022)\end{array}$ \\
\hline KSh 7,501-15,000 & $\begin{array}{l}0.357 * * * \\
(0.065)\end{array}$ & $\begin{array}{l}0.279 * * * \\
(0.059)\end{array}$ & $\begin{array}{l}0.170 * * * \\
(0.023)\end{array}$ \\
\hline KSh $15,001-30,000$ & $\begin{array}{l}0.367 * * * \\
(0.070)\end{array}$ & $\begin{array}{l}0.259 * * * \\
(0.061)\end{array}$ & $\begin{array}{l}0.209 * * * \\
(0.026)\end{array}$ \\
\hline KSh $30,001-70,000$ & $\begin{array}{l}0.498 * * * \\
(0.074)\end{array}$ & $\begin{array}{l}0.245 * * * \\
(0.066)\end{array}$ & $\begin{array}{l}0.316^{* * *} \\
(0.046)\end{array}$ \\
\hline KSh 70,001 - 400,000 & $\begin{array}{l}0.514 * * * \\
(0.125)\end{array}$ & $\begin{array}{l}0.196 * * * \\
(0.081)\end{array}$ & $\begin{array}{l}0.418 * * * \\
(0.076)\end{array}$ \\
\hline Above KSh 400,000 & $\begin{array}{l}0.267 * * * \\
(0.069)\end{array}$ & $\begin{array}{l}0.125^{* * *} \\
(0.062)\end{array}$ & $\begin{array}{l}0.179 * * * \\
(0.029)\end{array}$ \\
\hline Other & $\begin{array}{l}0.242 * * * \\
(0.071)\end{array}$ & $\begin{array}{l}0.089 \\
(0.065)\end{array}$ & $\begin{array}{l}0.143 * * * \\
(0.033)\end{array}$ \\
\hline Main Economic Activity & & & \\
\hline Employed & $\begin{array}{l}0.084 * * * \\
(0.027)\end{array}$ & $\begin{array}{l}0.015 \\
(0.021)\end{array}$ & $\begin{array}{l}0.067 * * * \\
(0.023)\end{array}$ \\
\hline Casual & $\begin{array}{l}-0.013 \\
(0.019)\end{array}$ & $\begin{array}{l}0.026^{*} \\
(0.016)\end{array}$ & $\begin{array}{l}-0.084 * * * \\
(0.016)\end{array}$ \\
\hline Own Business & $\begin{array}{l}0.070 * * * \\
(0.021)\end{array}$ & $\begin{array}{l}0.096 * * * \\
(018)\end{array}$ & $\begin{array}{l}-0.012 \\
(0.018)\end{array}$ \\
\hline Dependent & $\begin{array}{l}-0.046^{* * * *} \\
(0.021)\end{array}$ & $\begin{array}{l}-0.016 \\
(0.018)\end{array}$ & $\begin{array}{l}-0.082 * * * \\
(0.017)\end{array}$ \\
\hline Other & $\begin{array}{l}-0.069 \\
(0.054)\end{array}$ & $\begin{array}{l}-0.031 \\
(0.048)\end{array}$ & $\begin{array}{l}0.022 \\
(0.049)\end{array}$ \\
\hline Financially healthy & & & \\
\hline Yes & $\begin{array}{l}0.141 * * * \\
(0.018)\end{array}$ & $\begin{array}{l}0.111 * * * \\
(0.016)\end{array}$ & $\begin{array}{l}0.087 * * * \\
(0.014)\end{array}$ \\
\hline Financially literate & & & \\
\hline Yes & $\begin{array}{l}0.044 * * * \\
(0.014)\end{array}$ & $\begin{array}{l}0.052 * * * \\
(0.012)\end{array}$ & $\begin{array}{l}0.014 \\
(0.011)\end{array}$ \\
\hline Trust in Bank/Sacco & & & \\
\hline Yes & $\begin{array}{l}0.160^{* * *} \\
(0.014)\end{array}$ & $\begin{array}{l}0.050 * * * \\
(0.023)\end{array}$ & $\begin{array}{l}0.073 * * * \\
(0.020)\end{array}$ \\
\hline $\begin{array}{l}\text { Travelling Cost to Bank } \\
\text { Above KSh } 200\end{array}$ & $\begin{array}{l}-0.048^{* * * *} \\
(0.014) \\
\end{array}$ & $\begin{array}{l}-0.040 * * * \\
(0.013) \\
\end{array}$ & $\begin{array}{l}-0.035 * * * \\
(0.013) \\
\end{array}$ \\
\hline
\end{tabular}

Note: $t$ statistics in parentheses $* \mathrm{p}<0.05, * * \mathrm{p}<0.01, * * * \mathrm{p}<0.001$

The estimated formal saving model indicates that all the coefficients are statistically significant apart from the coefficient for females and casual workers. Household size, Age squared, Female, Casual labour and Dependent population reported an inverse relationship to formal savings. The findings are consistent with theory and findings from past empirical studies. The result presents financial service providers with a great opportunity to design savings products targeting specific population segments based on the reported marginal effects. Although the regression results capture demand for savings from digital, formal and informal sources, the discussion is centred on demand for formal savings, which combines both digital and traditional saving products.

The marginal effects for household size which is measured by the total number of people in a household shows that increase in the family size by one person from the mean reduces the savings potential for both digital and non-digital savers by 1.6 and 0.7 percent respectively. A similar study on the saving behaviour in Mozambique established an inverse relationship between increase in household size and savings (Amimo et al., 2003). This explains why most people prefer smaller families today, due to resource constraints, which limit access due to various competing needs. With every new family member beyond the mean household size of four, comes added expenditure whose impact is a reduction in disposable income. Given the inverse relationship between reduction in income and savings, an increase in household size reduces the saving probability and particularly from formal institutions and a substitution of the same towards informal savings.

The age variable is significant in influencing usage of both formal digital and formal non-digital savings in Kenya. This explains the positive coefficient for age and the negative coefficient for the squared age variable, which symbolize the presence of a quadratic relationship between age and formal savings. Ceteris paribus, a one- 
year increase in a person's age from the mean increases formal savings by 0.4 percent with the marginal changes turning negative with advancement in age. This conforms to findings by Elbadawi and Mwega, 2000; Amimo et al., 2003; Kibet et al., 2009. However, the age factor is more significant for non-digital savers than it is for digital savers.

One's gender is not a major consideration in savings going by the aggregated formal savings position. However, females reported a 2.7 percent lower probability of saving digitally as compared to their male counterparts. Kibet et al., 2009 has established a strong link between the gender of the household head and household savings in Kenya. On urbanization, Atieno (2001) predicted a strong positive link between urban residents and formal savings probability. This could be partly because formal finance is predominant in urban areas. Loayza, et al., 2000 however, in a cross-country study established a negative relationship between urbanization and private saving rate. The estimated model in this study found urban residents to enjoy a 4.6 percent higher probability of saving formally as compared to their rural counterparts. The degree of urbanization is only significant for digital savers. Residing in an urban setup therefore does not matter for non-digital savers.

Amimo et al., 2003; Kibet et al., 2009 associate education of the household head to improved saving behaviour. Consistent with their prediction, educated households in this study exhibited a higher probability of saving formally. Tertiary education holders accounted for the highest increase in the saving probability relative to having no education. Not having any formal education therefore disadvantages individuals in terms of usage of formal savings. This is evidenced by the 24.2 percent and 17.4 percent higher probability of tertiary education holders saving digitally and non-digitally respectively. These results indicate that educating the public boosts access to formal savings significantly. According to Kiiza \& Pederson, 2002, education is associated with increased awareness on access to financial services.

Education also provides guidance on the best management practises of existing financial services. This result is aligned to the effect of financial literacy on savings. Chowa et al., (2012) study on savings in Uganda linked increased savings to financial education. However, a study by William et al., (2012) in their study on the impact of financial education on savings among American households reported mixed results depending on the target population. Financial literacy in the context of this paper is aimed at testing effective numeracy and literacy by calculating the interest rate charged on loans. Based on the understanding of interest rates and the ability to calculate interest on loan, persons classified as being financially literate were found to have a 5.2 percent higher probability of saving digitally. This result also matches Hilgert, Hogarth and Beverly (2003) findings, which established a positive link between financial education and household behaviour.

Consumption and saving theories predict a strong positive link between income and household savings. This hypothesis has been confirmed empirically by Carpenter and Jensen, 2002; Kiiza \& Pederson, 2002; Amimo et al., 2003; Kibet et al., 2009 among others. The current study on Kenya also found the marginal propensity to save formally rising with income although diminishing marginal returns are observed at higher income levels (above KSh 400,000). Households earning between KSh $101-1500$ per month have a 15.6 per cent higher probability of saving formally compared to their counterparts earning between KSh 1-100 per month. A similar trend is observed for other income levels where income groups earning between KSh 1,501-3,000, KSh 3,001-7,500, KSh 7,50115,000, KSh 15,001-30,000, KSh 30,001-70,000 and KSh 70,001-400,000 were found to have a 25.5 per cent, 28.6 per cent, 35.7 per cent, 36.7 per cent, 49.8 per cent and 51.4 per cent higher probability of saving formally respectively. The impact of income on household savings on digital borrowers is more pronounced for low-income earners (KSh 1,501 - 30,000) while that on non-digital borrowers is more pronounced among high income earners (Above KSh 30,000).

The livelihood variable compares the probability of saving formally by one's main economic activity with agriculture being the reference category. Employed persons have an 8.4 per cent higher probability of saving formally compared to those working in the agriculture sector. Conversely, business entrepreneurs in Kenya have a 7.0 per cent higher probability of saving formally compared to workers in the agriculture sector. Interestingly, the impact is significantly higher on digital savings averaging 9.6 percent. This explains the huge reliance on mobile money and mobile banking technology among entrepreneurs. The dependent population reported a 4.6 per cent lower probability of saving formally compared to those working in the agriculture sector. The livelihood category mainly comprises students and the elderly who rely on friends, family and government transfers for their daily subsistence. The findings are consistent with Amimo et al., (2003) study in Mozambique, Njenga, Onuonga \& Sichei (2018) and Kibet et al., (2009) studies on Kenya who found savings to fall with increase in dependency ratio. The argument is that an additional dependant unit raises household expenditure thus lowering the savings.

The study also tests the relationship between financial health and savings probability in Kenya. A household's financial health is measured by assessing their ability to use financial services to manage their day-to-day needs, mitigate potentially catastrophic shocks and achieve their goals (FinAccess, 2019). Select variables, which include saving for old age, putting money aside for future use, ability to raise money during emergencies, gone without food among others were used to construct a financial health index. This index is included in the model to estimate the impact of ones' financial health status on formal savings probability. The study found financially healthy 
persons estimated to be 21.7 percent of the total adult population to have a 14.1 per cent higher probability of saving formally compared to the non-financially healthy population. This implies that an improvement in the overall financial wellbeing is a driver of household saving behaviour.

The study also sought to establish the role played by one's marital status on formal savings. The study established that married persons have a 4.7 percent higher probability of saving formally compared to the nonmarried ones. The effect is more pronounced among digital savers who reported a 4.8 percent higher probability of saving. When two mature adults come together in a marriage union, the pulling together of the accumulated resources could raise their total wealth. The positive and significant impact of marital status on household savings could therefore conforms to the consumption and savings theories.

Njenga, Onuonga \& Sichei (2018) included household perception about trust in various financial service providers in influencing savings. They found the saving probability to rise for those whose perception about trust in banks was high. This was affirmed by an assessment of the relationship between trust in Banks when in need of financial assistance and savings potential where a strong positive relationship was established. This was on the premise that households act rationally in their choice of saving mode. Households who had developed trust in Banks were found to have a 16 percent higher probability of saving in a formal institution.

In their pursuit of lifetime goals including saving in formal financial institutions, some price has to be paid. To proxy the cost of formal services, the study included the transport cost incurred in Kenya shillings to access the nearest Bank using public transport. Consistent with Kibet et al., (2009) and Njenga, Onuonga \& Sichei (2018) the study established an inverse relationship between price and formal savings. Households spending more than KSh 200 were found to have a 4.8 percent lower probability of saving formally as compared to smaller spenders.

\subsection{Conclusions and Implications for policy \\ 5.1 Conclusions}

Exposing the public to formal education and financial literacy programs could help create awareness on the usefulness of various financial services including savings and effective management to enhance optimal utilization. Household's choice of savings products is largely motivated by demographic characteristics. In particular, the age of a household was found to boost formal saving probability upto a certain point before it starts to decline with advancement in age.

Though the gender coefficient does not significantly explain the observed variation in formal saving, women were found to have a 3 percent lower probability of digital saving relative to males. However, formal savings were found to rise with income and the degree of urbanization. The same applies to formal employment; trust in banks, marital status and financial health. Household size as measured by the total number of family members and increase in transport cost to the bank was found to be inversely related. This implies that having a large family could be counterproductive in relation to formal saving probability due to the reduced disposable income. Increase in income as stated earlier was found to significantly raise formal saving.

Finally yet importantly, being financially unhealthy was found to be a hindrance to formal savings probability. This is rationalised by the reduction in household wellbeing whenever a household loses the ability to invest in livelihoods, cope with risks and management of day-to-day needs.

\subsection{Recommendations}

Pundits believe that increase in access to saving products would improve investment spurring overall economic growth. Given the current saving rates in Kenya, this study recommends an aggressive campaign to promote saving in formal channels. In addition, the government should champion the implementation of financial literacy programs to increase the effectiveness and uptake of saving products. Given the critical role that income continues to play in raising access to financial services, the government should create a conducive environment for businesses to thrive. This is in addition to creating more employment opportunities.

\subsection{Areas for further Research}

More studies on financial literacy should be encouraged to bring out the outcomes of financial education programmes. This will also help to state the depth to which financial service providers should factor in financial literacy while designing their products.

The study further recommends deep dive studies on saving in secret hiding places to understand its composition, drivers and barriers and profile of users.

\section{References}

Adewuyi, A. O., Bankole, A. S. \& Arawomo, D. F.(2010) What Determines Saving in the Economic Community of West African State (ECOWAS) in West African Journal Of Monetary And Economic Integration,10(2) : 71-99

Amimo, O.,Larson, D.,Bittencourt, M., and Graham, D.(2003). The Potential for Financial Savings in Rural 
Mozambican Households. Paper Presented in the 25th International Conference of Agricultural Economists. International Association of Agricultural Economists (IAAE). Durban, South Africa

Aryeetey, E. (2004). Household Asset Choice among the Rural Poor in Ghana, Institute of Statistical, Social and Economic Research, University of Ghana and Cornell University

Atieno R (2001). Formal and informal institution' lending policies and access to credit by small-scale enterprises in Kenya: an empirical assessment. African Economic Research Consortium. Nairobi. Research paper 111.

Blanchard, O., Amighini, A. and Giavazzi, F. (2017). Macroeconomics a European Perspective. $3^{\text {rd }}$ edition. Pearson

Boring, I. (2010). An Empirical Analysis of Household Savings Behavior in Uganda. Andrew Young School of Policy Studies, Georgia State University.

Carpenter, S., and Jensen, R. (2002). Household Participation in Formal and Informal Savings Mechanisms: Evidence from Pakistan, Review of Development Economics, 6(3), 314-328.

Central Bank of Kenya, Kenya National Bureau of Statistics and FSD Kenya (2019). The 2019 FinAccess Report

Chowa GAN, Masa R, Ansong D (2012). Determinants of saving among low income individuals in rural Uganda: Evidence from assets Africa. Advances in Applied Sociology, 2(4):280-291.

Diamond, P. (1965). National Debt in a Neo-Classical Growth Model. American Economic Review, 55, 1126-1150.

Duesenberry, J. (1949). Income, Saving and the Theory of Consumer Behavior. Cambridge, Harvard University Press.

Elbadawi I. A. \& Mwega, F. M. (2000). Can Africa's Saving Collapse Be Reversed? The World Bank Economic Review, 14(3):415-443.

Ersado, L., Alwang, J., \& Alderman, H. (2000). Changes in Consumption and Saving Behavior before and after Economic Shocks: Evidence from Zimbabwe, International Food and Agribusiness Management Association Conference in Chicago, 25 -28 June, 2000. Retrieved from http://ideas.repec.org/a/ucp/ecdecc/y2003v52i1p187-215.html

Friedman, M. (1957). A Theory of the Consumption Function. National Bureau of Economic Research, General Series No. 63. New Jersey: Princeton University Press.

Hall, R. (1978). Stochastic Implications of the Life Cycle-Permanent Income Hypothesis: Theory and Evidence. Journal of Political Economy, 86, 971-987

Hilgert, Hogarth and Beverly (2003). Household Financial Management: The Connection between Knowledge and Behavior. Federal Reserve Bulletin, issue 309-322

Kauffmann Barbara (1991). Microeconomics of saving. Economic Papers. Commission of the European Communities, No. 89

Keynes, J. (1936). The General Theory of Employment, Interest and Money. New York: Harcourt, Brace \& Co.

Kibet, L. K., Mutai, B. K., Ouma, D. E., Ouma, S. A. and Owuor, G. (2009). Determinants of household saving: Case study of Smallholder farmers, entrepreneurs and teachers in rural areas of Kenya. Journal of Development and Agricultural Economics, 1(7), 137-143.

Kiiza, B., and Pederson, G. (2002). Household Financial Savings Mobilization: Empirical Evidence from Uganda. Journal of African Economies 10(4), 390-409.

King, M. (1985). "The Economics of Saving: A Survey of Recent Contributions." In Frontiers of Economics.Edited by K. Arrow and S. Houkapohja. New York: Basil Blackwell. Pages 227-294

Loayza,N., Hebbel K. S. \& Servén, L. (2000), What Drives Private Saving across the World? The Review of Economics and Statistics 82 (2): 165-181.

McFadden D (1974). Conditional logit analysis of qualitative choice behavior. Frontiers. pp. 105-142

Milton, F. (1957). Introduction to A Theory of Consumption Functionll. National Bureau of Economic Research (NBER).

Ministry of Planning and National Development. (2007). Kenya Vision 2030: The Popular Vision. Retrieved from http://www.planning.go.ke/index.php?option=com_docman.

Modigliani, Franco, and Richard Brumberg, "Utility Analysis and the Consumption Function: An Interpretation of Cross-Section Data," in K. Kurihara, ed., PostKeynesian Economics (New Brunswick, NJ: Rutgers University Press, 1954).

Modigliani, F. (1963). The Life Cycle Hypothesis of Saving: Aggregate Implication and Test, American Economic Review 53 (1), 55-84.

Mwega, M., Ngola, M., \& Mwangi, N. (1990). Real Interest Rates and the Mobilization of Private Savings in Africa. A Case Study of Kenya. AERC Research Paper No. 2, Nairobi.

Newman, C., Tarp, F., Broek, K., Quang, C., and Khai, L. (2007). Household Savings in Vietnam: Insights from a 2006 Rural Household Survey

Nga, M. T. (2007). An Investigative Analysis into the Saving Behavior of Poor Households in Developing Countries: with specific reference to South Africa. Retrieved from http://etd.uwc.ac.za/usrfiles/modules/etd/docs/etd_gen8Srv25Nme4_3201_1190379022.pdf 
Njenga G., Onuonga S.M., \& Sichei M.M. (2018). Institutions' effect on households' savings in Kenya: A ranked ordered multinomial/conditional probit model approach. Journal of Economics and International Finance, Vol. 10(5), pp. 43-57

Rabindra Bhandari, Dharmendra Dhakal, Gyan Pradhan and Kamal P. (2007). Determinants of Private Saving in South Asia. South Asia Economic Journal 2007 8: 205

Republic of Kenya. (1965). African Socialism and its Application to Planning in Kenya. Sessional Paper No. 10: Nairobi: Government printer

Rogg, C. (2000). The Impact of Access to Credit on the Saving behavior of Micro-entrepreneurs: Evidence from Three Latin American Countries. A paper based on a Thesis submitted to the University of Oxford in June 1999.

Romer, D. (2005). Advanced Macroeconomics $3^{\text {rd }}$ edition, University of California, Berkeley.

Schunk, D. (2007). What determines the saving behaviour of German households? An Examination of Saving Motives and Saving Decisions. MEA Working Paper 124. Retrieved from http://ideas.repec.org/p/xrs/sfbmaa/07-10.html

Solow. R. (1956). A contribution to the theory of economic growth. The Quarterly Journal of Economics, 70(1), 65

United Nations. (1962). Economic Bulletin for Asia and the Far East, 13(3)

William G. Gale, Benjamin H. Harris, and Ruth Levine (2012). Raising Household Saving. Does Financial Education Work? Social Security Bulletin, Vol. 72, No. 2, 2012

World Bank. (1993). The East Asian Miracle: Economic Growth and Public Policy. World Bank Policy Research Report. New York: Oxford University Press.

Appendix Table 5: Sampling Distribution

\begin{tabular}{|c|c|c|c|c|c|c|c|}
\hline \multirow{2}{*}{ Region } & \multirow{2}{*}{ County } & \multicolumn{3}{|c|}{ Allocation of Clusters } & \multicolumn{3}{|c|}{ Allocation of households } \\
\hline & & Rural & Urban & Total & Rural & Urban & Total \\
\hline NAIROBI & NAIROBI & na & 74 & 74 & na & 814 & 814 \\
\hline NORTH RIFT & TURKANA, WEST POKOT, SAMBURU & 36 & 14 & 50 & 396 & 154 & 550 \\
\hline CENTRAL RIFT & \begin{tabular}{|l|} 
TRANS NZOIA, BARINGO, UASIN \\
GISHU, ELGEYO-MARAKWET, NANDI, \\
LAIKIPIA, NAKURU
\end{tabular} & 70 & 46 & 116 & 770 & 506 & 1,276 \\
\hline SOUTH RIFT & NAROK, KAIIADO, KERICHO, BOMET & 52 & 31 & 83 & 572 & 341 & 913 \\
\hline NYANZA & $\begin{array}{l}\text { SIAYA, KISUMU, MIGORI, HOMA } \\
\text { BAY, KISII, NYAMIRA }\end{array}$ & 71 & 41 & 112 & 781 & 451 & 1,232 \\
\hline WESTERN & $\begin{array}{l}\text { KAKAMEGA, VIHIGA, BUNGOMA, } \\
\text { BUSIA }\end{array}$ & 64 & 31 & 95 & 704 & 341 & 1,045 \\
\hline CENTRAL & $\begin{array}{l}\text { NYANDARUA, NYERI, KIRINYAGA, } \\
\text { MURANG'A, KIAMBU }\end{array}$ & 70 & 47 & 117 & 770 & 517 & 1,287 \\
\hline LOWER EASTERN & KITUI, MACHAKOS, MAKUENI & 52 & 32 & 84 & 572 & 352 & 924 \\
\hline UPPER EASTERN & MARSABIT, ISIOLO & 18 & 13 & 31 & 198 & 143 & 341 \\
\hline MID-EASTERN & MERU, THARAKA, EMBU & 51 & 22 & 73 & 561 & 242 & 803 \\
\hline COASTAL REGION & $\begin{array}{l}\text { KWALE, KILIFI, TANA RIVER, LAMU, } \\
\text { TAITA TAVETA }\end{array}$ & 45 & 25 & 70 & 495 & 275 & 770 \\
\hline NORTH EASTERN & GARISSA, WAJIR, MANDERA & 37 & 19 & 56 & 407 & 209 & 616 \\
\hline MOMBASA & MOMBASA & na & 39 & 39 & na & 429 & 429 \\
\hline KENYA & & 566 & 434 & 1,000 & 6,226 & 4,774 & 11,000 \\
\hline
\end{tabular}

Source: FinAccess 2019 Report 
Appendix Table 6: Multinomial Probit Estimation

\begin{tabular}{|c|c|c|}
\hline & Formal Savings & Informal Savings \\
\hline Household Size & $\begin{array}{l}-0.019 * * * \\
(0.003)\end{array}$ & $\begin{array}{l}0.003 * * \\
(0.002)\end{array}$ \\
\hline Age & $\begin{array}{l}0.004 * * \\
(0.002)\end{array}$ & $\begin{array}{l}0.006^{* * *} \\
(0.001)\end{array}$ \\
\hline Age squared & $\begin{array}{l}-0.00006^{* * * *} \\
(0.000)\end{array}$ & $\begin{array}{l}-0.00005 * * * \\
(0.00001)\end{array}$ \\
\hline \multicolumn{3}{|l|}{ Gender } \\
\hline Female & $\begin{array}{l}-0.021 \\
(0.012)\end{array}$ & $\begin{array}{l}0.090 * * * \\
(0.007)\end{array}$ \\
\hline \multicolumn{3}{|l|}{ Marital Status } \\
\hline Married & $\begin{array}{l}0.051 * * * \\
(0.012)\end{array}$ & $\begin{array}{l}0.014 * * \\
(0.007)\end{array}$ \\
\hline \multicolumn{3}{|l|}{ Residence } \\
\hline Urban & $\begin{array}{l}0.053 * * * \\
(0.015)\end{array}$ & $\begin{array}{l}-0.005 \\
(0.007)\end{array}$ \\
\hline \multicolumn{3}{|c|}{ Highest Education Attained } \\
\hline Primary & $\begin{array}{l}0.227 * * * \\
(0.029)\end{array}$ & $\begin{array}{l}-0.003 \\
(0.012)\end{array}$ \\
\hline Secondary & $\begin{array}{l}0.263 * * * \\
(0.032)\end{array}$ & $\begin{array}{l}-0.014 \\
(0.014)\end{array}$ \\
\hline Tertiary & $\begin{array}{l}0.288 * * * \\
(0.037)\end{array}$ & $\begin{array}{l}-0.021 \\
(0.018)\end{array}$ \\
\hline Other & $\begin{array}{l}0.350 * * * \\
(0.115)\end{array}$ & $\begin{array}{l}-0.088^{* * *} \\
(0.011)\end{array}$ \\
\hline \multicolumn{3}{|l|}{ Income per Month } \\
\hline KSh $101-1,500$ & $\begin{array}{l}0.161 * * * \\
(0.073)\end{array}$ & $\begin{array}{l}-0.028 \\
(0.042)\end{array}$ \\
\hline KSh $1,501-3,000$ & $\begin{array}{l}0.277 * * * \\
(0.072)\end{array}$ & $\begin{array}{l}-0.005 \\
(0.042)\end{array}$ \\
\hline KSh 3,001-7,500 & $\begin{array}{l}0.312 * * * \\
(0.073)\end{array}$ & $\begin{array}{l}-0.019 \\
(0.042)\end{array}$ \\
\hline KSh 7,501-15,000 & $\begin{array}{l}0.392 * * * \\
(0.072)\end{array}$ & $\begin{array}{l}-0.040 \\
(0.042)\end{array}$ \\
\hline KSh $15,001-30,000$ & $\begin{array}{l}0.403 * * * \\
(0.077)\end{array}$ & $\begin{array}{l}-0.038 \\
(0.044)\end{array}$ \\
\hline KSh $30,001-70,000$ & $\begin{array}{l}0.540 * * * \\
(0.079)\end{array}$ & $\begin{array}{l}-0.050 \\
(0.045)\end{array}$ \\
\hline KSh 70,001-400,000 & $\begin{array}{l}0.578 * * * \\
(0.103)\end{array}$ & $\begin{array}{l}-0.030 \\
(0.077)\end{array}$ \\
\hline Above KSh 400,000 & $\begin{array}{l}0.297 * * * \\
(0.077)\end{array}$ & $\begin{array}{l}0.005 \\
(0.046)\end{array}$ \\
\hline Other & $\begin{array}{l}0.271 * * * \\
(0.079)\end{array}$ & $\begin{array}{l}-0.040 \\
(0.045)\end{array}$ \\
\hline \multicolumn{3}{|l|}{ Main Economic Activity } \\
\hline Employed & $\begin{array}{l}0.096 * * * \\
(0.031)\end{array}$ & $\begin{array}{l}-0.004 \\
(0.016)\end{array}$ \\
\hline Casual & $\begin{array}{l}-0.015 \\
(0.023)\end{array}$ & $\begin{array}{l}0.004 \\
(0.010)\end{array}$ \\
\hline Own Business & $\begin{array}{l}0.084 * * * \\
(0.025)\end{array}$ & $\begin{array}{l}0.002 \\
(0.013)\end{array}$ \\
\hline Dependent & $\begin{array}{l}-0.054 * * * \\
(0.025)\end{array}$ & $\begin{array}{l}-0.017^{*} \\
(0.011)\end{array}$ \\
\hline Other & $\begin{array}{l}-0.081 \\
(0.067)\end{array}$ & $\begin{array}{l}-0.065^{* * *} \\
(0.016)\end{array}$ \\
\hline Financially healthy & & \\
\hline Yes & $\begin{array}{l}0.160 * * * \\
(0.020)\end{array}$ & $\begin{array}{l}-0.005 \\
(0.012)\end{array}$ \\
\hline Financially literate & & \\
\hline Yes & $\begin{array}{l}0.057 * * * \\
(0.016)\end{array}$ & $\begin{array}{l}0.009 \\
(0.009)\end{array}$ \\
\hline Trust in Bank/Sacco & & \\
\hline Yes & $\begin{array}{l}0.181 * * * \\
(0.027)\end{array}$ & $\begin{array}{l}-0.030 \\
(0.014)\end{array}$ \\
\hline $\begin{array}{l}\text { Travelling Cost to Banl } \\
\text { Above KSh } 200\end{array}$ & $\begin{array}{l}-0.058 * * * \\
(0.019)\end{array}$ & $\begin{array}{l}0.016 \\
(0.009)\end{array}$ \\
\hline
\end{tabular}

